\title{
Erratum to: Beauty will save the world, but will the world save beauty? The case of the highly endangered Vavilovia formosa (Stev.) Fed.
}

\author{
Aleksandar Mikić • Petr Smýkal • Gregory Kenicer • Margarita Vishnyakova • Nune Sarukhanyan • \\ Janna A. Akopian • Armen Vanyan • Ivan Gabrielyan • Iva Smýkalová • Ekaterina Sherbakova • \\ Lana Zorić · Jovanka Atlagić • Tijana Zeremski-Škorić • Branko Ćupina • Đorđe Krstić • \\ Igor Jajić • Svetlana Antanasović · Vuk Đorđević • Vojislav Mihailović • Alexandr Ivanov • \\ Sergio Ochatt $\cdot$ Cengiz Toker $\cdot$ Bojan Zlatković $\cdot$ Mike Ambrose
}

Published online: 24 September 2014

(C) Springer-Verlag Berlin Heidelberg 2014

\section{Erratum to: Planta}

DOI 10.1007/s00425-014-2136-9

This Erratum is addressing the reuse of four figures without the proper acknowledgement of the original source.

Figures 2, 3, 6 and 7 in this article were reproduced from the work of Mikić, A., Smýkal, P., Kenicer, G., Vishnyakova, M., Sarukhanyan, N., Akopian, J., Vanyan,

The online version of the original article can be found under doi:10.1007/s00425-014-2136-9.

\footnotetext{
A. Mikić $(\varangle)$ · J. Atlagić · T. Zeremski-Škorić · V. Đorđević · V. Mihailović

Institute of Field and Vegetable Crops, Maksima Gorkog 30,

21000 Novi Sad, Serbia

e-mail: aleksandar.mikic@nsseme.com;

aleksandar.mikich@gmail.com

P. Smýkal

Palacký University at Olomouc, Olomouc, Czech Republic

G. Kenicer

Royal Botanical Garden Edinburgh, Edinburgh, UK

M. Vishnyakova

State Scientific Centre N.I. Vavilov All-Russian Research Institute of Plant Industry of Russian Academy of Agricultural

Science, St. Petersburg, Russia

N. Sarukhanyan · A. Vanyan

Green Lane Agricultural Assistance NGO, Yerevan, Armenia

J. A. Akopian - I. Gabrielyan · E. Sherbakova

National Academy of Sciences, Institute of Botany, Yerevan,

Armenia

I. Smýkalová

Agritec Plant Research Ltd., Šumperk, Czech Republic
}

A., Gabrielyan, I., Smýkalová, I., Sherbakova, E., Zorić, L., Atlagić, J., Zeremski-Škorić, T., Ćupina, B., Krstić, Đ., Jajić, I., Antanasović, S., Đorđević, V., Mihailović, V., Ivanov, A., Ochatt, S. and Ambrose, M. (2013), The bicentenary of the research on 'beautiful' vavilovia ( $\mathrm{Va}$ vilovia formosa), a legume crop wild relative with taxonomic and agronomic potential. Botanical Journal of the Linnean Society, Volume 172, Issue: 4, Pages: 524-553, by kind permission from John Wiley \& Sons, Inc.
L. Zorić

Department of Biology and Ecology, Faculty of Sciences, University of Novi Sad, Novi Sad, Serbia

B. Ćupina · Đ. Krstić · I. Jajić · S. Antanasović Department of Field and Vegetable Crops, Faculty of Agriculture, University of Novi Sad, Novi Sad, Serbia

A. Ivanov

Botany Department Herbarium, Stavropol State University, Stavropol, Russia

S. Ochatt

INRA, UMR1347, PCMV, Dijon, France

C. Toker

Akdeniz University, Antalya, Turkey

B. Zlatković

Department of Biology and Ecology, Faculty of Sciences and Mathematics, University of Niš, Niš, Serbia

M. Ambrose

Department of Crop Genetics, John Innes Centre, Norwich, UK 